\title{
Ruminantlarda Mycobacterium avium subspecies paratuberculosis Enfeksiyonunun İmmunolojik Özellikleri
}

\author{
Ezgi Şababoğlu, Hülya Türütoğlu \\ Mehmet Akif Ersoy Üniversitesi, Veteriner Fakültesi, Mikrobiyoloji Anabilim Dall, Burdur
}

Geliş Tarihi / Received: 10.04.2017, Kabul Tarihi / Accepted: 23.10.2017

\begin{abstract}
Özet: Mycobacterium avium subspecies paratuberculosis, hayvan sağlığını etkileyen ve ciddi ekonomik kayıplara sebep olan önemli bir patojendir. Etkenin mevcut immun sistemden kaçma stratejileri nedeniyle bugüne kadar paratüberküloza karş1 etkili bir aşı geliştirilememiş ve uygun bir koruma ve kontrol stratejisi belirlenememiştir. M. avium subsp. paratuberculosis'e karşı doğru kontrol stratejilerinin geliştirilebilmesi için konakçı-patojen etkileşimini düzenleyen hücresel ve moleküler mekanizmalar ile hastalığın patolojik temelinin detaylı olarak anlaşılması gerekmektedir. Bu derlemede; M. avium subsp. paratuberculosis ile konakçı ilişkisi ve konakçıda gelişen immunolojik reaksiyonlar üzerine kapsamlı bilgiler sunuldu.
\end{abstract}

Anahtar kelimeler: İmmünoloji, konakçı savunmas1, Mycobacterium avium subspecies paratuberculosis

\section{Immunological Characteristics of Mycobacterium avium subspecies paratuberculosis Infection in Ruminants}

\begin{abstract}
Mycobacterium avium subspecies paratuberculosis is an important pathogen that affects animal health and causes serious economic loss. Due to the current strategy of escape from the immunity system, so far, an effective vaccine against paratuberculosis has not been developed and no appropriate protection and control strategy has been determined. In order to develop correct control strategies against $M$ avium subsp paratuberculosis, cellular and molecular mechanisms regulating the host-pathogen interaction and the pathological basis of the disease must be understood in detail. In this review M. avium subsp. paratuberculosis-host interactions and the information on the immunological reactions developed in the host were presented.
\end{abstract}

Keywords: Host defense, immunology, Mycobacterium avium subspecies paratuberculosis

\section{Giriş}

Paratüberküloz (Johne hastalı̆̆ı), Mycobacterium avium subspecies paratuberculosis (Map) tarafından oluşturulan, kronik granülomatöz enterokolitis, bölgesel lenfanjitis ve lenfadenitis ile karakterize yavaş gelişen hatta ölümle sonuçlanabilen bir hastalıktır [36, 41]. Evcil ve yabani ruminantlarda (sığır, koyun, keçi, bizon, geyik, alpaka, lama, deve, manda) ve ruminant olmayan yabani türlerde (tavşan, tilki, maymun, porsuk, çakal, kuş, kedi, rakun) $[3,20,23]$ hastalığa neden olmaktadır. Çok eskiden beri bilinen bir hastalık olmasına rağmen, patogenezi henüz tam olarak ortaya konulamamış ve dolayısıyla hastalığın kontrolü için etkili bir aşı veya uygun bir tedavi protokolü öngörülememiştir. Hayvan sağlığını tehdit eden ve büyük ekonomik kayıplara yol açan bu hastalığın önemi günümüzde halen devam etmektedir [20]. Ekonomik zararının yanı sıra ruminant paratüberkülozu ile insanların Crohn hastalığ edilmesi, son zamanlarda paratüberküloz hastalığının daha çok ilgi çekmesine yol açmıştır [24]. Crohn hastalarının ince barsaklarındaki histopatolojik bulguların paratüberküloza büyük benzerlik gösterdiği ve vakaların çoğunda paratüberküloz hastalığının etkeni olan Map ’in izole edildiği bildirilmesine rağmen, Map'in hastalığın oluşumundaki rolü kesin olarak ortaya konulamamıştır [4, 9]. Etkenin enfekte hayvanların dışkısının yanı sıra sütleriyle de atıldığ1 tespit edilmiş ve enfekte hayvanların süt ve süt ürünlerinin insanlar için potansiyel bir bulaşma kaynağ1 olabileceği ileri sürülmüştür $[4,13,16]$.

\section{Hastalığın Gelişim Evreleri ve Konakçı Yanıtı}

Ruminantlarda paratüberküloz farklı evrelerden oluşmakta ve konakçının patolojik durumlara kar- 
Ş1 gösterdiği immun yanıta bağlı olarak bu evreler erken, subklinik ve klinik enfeksiyon evresi olarak sinıflandirılmaktadır [23].

\section{Erken Evre}

Hastalığın erken evresi, 2 yaştan küçük hayvanlarda ya da Map'in düşük konsantrasyonlar1nın (501.0x103CFU) sindirim [20] veya vertikal [39] yol ile bulaştı̆̆ hayvanlarda görülmektedir. Konakçı tarafından sindirim yoluyla alınan Map'in, bağırsak ile ilişkili lenfoid dokuya (gut-associated lymphoid tissue, GALT) yerleştiği ve Payer plaklarında bulunan $\mathrm{M}$ hücreleri ile fibronektin köprüsü kurarak konakçıya girdiği bilinmektedir [20, 32]. Fibronektin köprüsünün yanısıra, Map'in epitel hücrelerine invaze olabileceği de bildirilmiştir $[20,30]$. Map'in, vücuda girdikten sonra intestinal makrofajlara invaze olma yeteneğine sahip olduğu ve çeşitli stratejilerle konakçı savunmasını engelleyerek makrofajların içlerinde yaşayıp replike olabildiği açıklanmıştır [20, 32]. Bakterinin makrofajlar içinde hayatta kalma stratejisini farklı mekanizmalar oluşturmaktadır. Bakterinin kullandığı bu mekanizmalar arasında; stres koşullarında spor benzeri yapı oluşturarak 1s1, lizozim ve proteinaz K'dan korunması [20], fagozom olgunlaşmasını inhibe etmesi, makrofaj apoptozisini ve fagozom asitleşmesini engellemesi [3, 10, 32], MHC molekülünün ekspresyonunu azaltması [32] ve sinyal iletim yollarını etkilemesi [1,33] sayılabilir.

Map'e karşı konakçı tarafindan oluşturulan doğal savunma mekanizması: Birçok mikroorganizmada bulunan ve oldukça korunmuş patojen ile ilişkili moleküler yapıları (pathogen associated molecular patterns, PAMP) taniyan reseptörler (pattern-recognition receptors, PRRs), PAMP'lar1 bağlayarak hücrelerarası sinyal yollarını oluşturur ve böylece immun sistem hücrelerinin yangıy1 uyaran molekülleri salgılamasina ve immun yanıtın uyarılmasına yol açarlar [29, 35]. Map'in endositozunda görevli fagositik hücrelerin üzerinde $M a p^{\prime}$ 'i bağlayan önemli PRR'ler bulunmaktadır. Bu reseptörler (PRR) arasında komplement reseptörleri (complement receptor, CR1, CR3, CR4), mannoz reseptörü (MR), membran proteinini bağlayan bir fosfatidilinositol olan CD14 [32], CD11a, CD18 gibi $\beta$-integrin reseptörleri [23], sürfaktan protein- ler, mannoz bağlayan lektinler (mannose-binding lectins, MBLs), C1q, IgG ile kaplı mikobakteriler için Fcy reseptörü [32], transferrin reseptörleri, toll benzeri reseptör (toll-like receptors, TLR) 2, TLR 4 [23] ve TLR 9 [2] bulunmaktadır. En önemli PRR'lerden olan TLR'ler ile immun sistem uyarılarak sitokin yanıtı başlatılır [29]. Fagozomal olgunlaşma gibi mikobakterilerin patogenezisinde önemli hücresel işlemler TLR aracılığıyla şekillenmektedir [29]. TLR üretimindeki artışın Map'e karşı koruyucu olduğu gösterilmiştir [3]. TLR'lerin farklı etkiye sahip olmaları nedeniyle paratüberküloza karşı gelişen immun yanıttaki rollerinin oldukça karışı olduğu bildirilmiş [3], TLR'lerde meydana gelen mutasyonların mikobakterilere karşı duyarlılı̆̆ 1 arttırdığ 1 ileri sürülmüştür [23].

Mikobakterilerin öldürülmesinde etkili mekanizmalar: Mikobakterilerin öldürülmesinde en önemli mekanizmanın makrofaj aktivasyonu oldugu, makrofaj aktivasyonunda ise interferon gama (IFN- $\gamma)$ ve tümör nekrozis faktör-beta (TNF- $\beta$ ) gibi proenflamatuar sitokinlerin rol oynadığ rilmiştir [32]. Lipopolisakkaritleri tanıyan TLR'ler tarafindan aktive olan monosit ve makrofaj gibi mononüklear fagositler tarafindan mikroorganizmaların sindirildiği, hücre içinde ise otofaji uyarılarak antimikrobiyal peptidler, reaktif oksijen/nitrojen ara ürünleri aracılığ rüldüğü açıklanmıştır $[31,40]$. D vitamininin aktif metaboliti olan 1, 25- dihidroksikolekalsiferol (kalsitriol, [1, $25(\mathrm{OH}) 2 \mathrm{D} 3])$ 'ün ise CD14 ve mannoz reseptörü gibi yüzey reseptörlerinin üretimini arttırarak makrofajların fagositoz yeteneğini güçlendirdiği, katelisidin ve defensinlerin ekspresyonunu arttırarak makrofajların antimikrobiyal etkisine katkıda bulunduğu ve ayrıca antijen sunumunun yan1sıra bazı kemokin, sitokin ve makrofaj faktörlerinin sekresyonunu da düzenlediği açıklanmıştır [31]. Serbest yağ asitlerinin ve granülizinin de antimikrobiyal aktiviteye sahip olduğu ve Mycobacterium tuberculosis $(M t b)$ 'in makrofajlar tarafindan öldürülmesinde önemli rol oynadığ 1 açıklanmıştır [32]. Bunun yanısıra apoptozisin de mikobakterinin yay1lımını engelleyen diğer bir mekanizma olduğu belirtilmiştir [32].

Konakçı tarafindan oluşturulan kazanılmış immun yant: Mikobakteri enfeksiyonlarının erken evresinde hücresel immun yanıtın çok önemli olduğu 
bilinmektedir. Ancak Map, hayatta kalabilmek için erken gelişen bu hücresel immun yanıtı engelleyen stratejiler geliştirmektedir [23]. Örneğin, Map makrofajları enfekte ettiğinde fagozom lizozom füzyonunu engeller ve mitojen ile aktive edilmiş protein kinaz (mitogen activated protein kinase, MAPK) düzeyini arttırır. MAPK, IL-10 sentezini arttırarak ve fagozom-lizozom füzyonunu engelleyerek bakterinin yaşamasına yardımcı olur [38]. Ayrıca TLR'lerde (TLR2 ve TLR4) de artış olur. Aktive edilen makrofajlar interleukin-1 (IL-1), tümör nekrozis faktör- $\alpha$ (TNF- $\alpha$ ) ve IL-12 gibi pro-enflamatuar sitokinleri üretir. IL-6, IL-8 ve IL10 'da artış gözlenir. IL-1'in artışı sonucunda IL-2 üreten $\mathrm{T}$ hücreleri aktive olur ve $\mathrm{CD} 4^{+}$yardımcı $\mathrm{T}$ hücrelerinin ve $\mathrm{CD} 8^{+}$sitozolik $\mathrm{T}$ hücrelerinin klonal çoğalmasına yol açar [32].

Paratüberkülozun erken aşamasında $\mathrm{CD}^{+} \mathrm{T}$ hücreleri oldukça önemlidir. Map makrofajlar tarafından fagosite edildikten sonra makrofajlar tarafından antijen sunumu gerçekleşir ve sitokinler aracılığıyla $\mathrm{CD}^{+} \mathrm{T}$ hücreleri aktive olarak hücresel immun yanıt şekillenir [6]. CD4 ${ }^{+} \mathrm{T}$ hücrelerinin alt tipleri intrasellüler Map'e karşı hücresel immun yanıtı aktive etmede görevlidir. Aktive edilmiş makrofajlar enfeksiyon bölgesine $\mathrm{CD}^{+} \mathrm{T}$ hücrelerini toplayan IL-12 ve kemokinleri salgilamaktadır. $\mathrm{CD}^{+}{ }^{+} \mathrm{T}$ hücreleri ya Th1 ya da Th2 hücrelerine farklılaşır. Th1 hücrelerinin aktivasyonu IFN- $\gamma$, IL-2 ve TNF- $\alpha$ sentezine neden olur [32]. Sentezlenen IFN- $\gamma$ da makrofajlara IL-12 salg1lanmas1 ve yang1sal değişiklikleri teşvik etmek üzere etki eder [23]. Ayrıca, B hücreleri de $\mathrm{CD}^{+} \mathrm{T}$ hücrelerine antijen sunarak daha fazla IFN- $\gamma$ sentezlenmesini sağlar [36]. IFN- $\gamma$, Th1 hücreleri aracılığıyla gelişen hücresel immun yanıtı da uyarır [23]. Diğer taraftan makrofajlar ve intestinal epitel hücreleri tarafindan üretilen IL-18'in de IFN- $\gamma$ üretimini arttırdığı belirtilmiştir [32].

Son yıllarda paratüberkülozun erken aşamasında gama-delta $\mathrm{T}(\gamma \delta \mathrm{T})$ hücrelerinin rolü üzerinde ça1ışılmaktadır. $\gamma \delta \mathrm{T}$ hücreleri 6 aylıktan küçük buzağılarda baskın olan T hücreleridir [32]. Buzağılarda sirkülasyondaki periferal kan mononüklear hücrelerinin yaklaşık \%40'ını, yetişkin sığırlarda ise \%1015'ini oluşturmaktadır [23]. Deneysel yapılan bir çalışmada; canlı Map içeren inokulumların enjekte edildiği buzağılarda $\gamma \delta \mathrm{T}$ hücrelerinin hastalığın er- ken döneminde enfeksiyon bölgesine göç ettikleri gösterilmiştir [26]. $\gamma \delta \mathrm{T}$ hücrelerinin antijenlerin $\mathrm{CD}^{+} \mathrm{T}$ hücrelerine sunulmasinda [23], canlı mikobakteri veya mikobakteriyel hücre duvarına karşı IFN- $\gamma$ üretiminde [15], IFN- $\gamma$ etkisi altında TNF- $\alpha$ salgilanmasında [32], intrasellüler ve ekstrasellüler $M t b$ etkenlerini granülizin salgılayarak öldürülmesinde, enfekte dendritik hücrelerden IL-17A salg1lanmasinda [21], IL-10 ve TGF- $\beta$ üretiminde [5], Th1 immun yanıtının düzenlenmesi ve diğer dokulardaki hasarı engellemek için granülasyon oluşumunda [32] görevli olduğu rapor edilmiştir. IL-15' in ise IL-12 reseptörlerini etkilediği ve intraepitelyal $\gamma \delta \mathrm{T}$ hücrelerini stimüle ettiği açıklanmıştır [32]. Diğer taraftan $\gamma \delta \mathrm{T}$ hücrelerinin, sistemik sirkülasyonda strese oldukça duyarlı oldukları ve bu nedenle strese maruz kalan hayvanların paratüberküloza daha duyarlı olabilecekleri ileri sürülmüştür [32].

Bazı araştırmacılar [10, 17], dışk1, süt, doku gibi örneklerde az miktarda basil bulunduran paratüberkülozlu hayvanlarda Th1 (IFN- $\gamma$ ) yanıtının, çok miktarda basil içeren hayvanlarda ise Th2 tip yanıtının daha ağırlıkta olduğunu bildirmiştir. Fazla sayıda basil bulunan sı ğırlarda IL-2, IL-4 ve IL-10 düzeylerinde artış gözlendiği belirtilmiştir [22]. Son yıllarda yapılan bazı çalışmalarda [27, 37], ise deneysel olarak enfekte edilen hayvanlarda IFN- $\gamma$ yanıtı gibi kısa bir sürede antikor yanıtının geliştiği saptanmıştır. Begg ve ark. [8] koyunlar üzerinde yürüttükleri deneysel çalışmalarında; enfekte koyunların \%39'unda immun yanıtın güçlü IFN- $\gamma$ yanıtından antikor yanıtına dönüştüğünü, \%50'sinde enfeksiyonun erken aşamasında IFN- $\gamma$ ve antikor yanıtının birlikte olduğunu, \%16'sında ise antijene spesifik antikor yanıtının engellediğini saptamışlar ve bu bulgulara göre enfekte koyunlarda Th1 yan1tının Th2 yanıtına dönüşmesinin yaygın olmadığını ileri sürmüşlerdir.

\section{Subklinik Evre}

Subklinik evre, paratüberkülozun 2-5 yıla kadar sürebilen uzun bir latent fazıdır [23]. Bu fazda enfekte hayvan klinik bulgu göstermez, sağlıklı görünür. Fakat bu fazın geç aşamalarında hayvanlar aralıklı olarak dişkı ile etkeni çıkarır ve antikor düzeyi genellikle düşüktür $[23,36]$. Bu evredeki hayvanla- 
rın yaklaşık \%10'unda IFN- $\gamma$ ve antikor düzeyleri tespit edilebilir bir seviyeye yükselir [7, 11]. Tan1 testlerinin yetersizliği veya Map'in aralıklı olarak çıkarılmasından dolayı subklinik enfekte hayvanların tespit edilmesi zordur ve bu durum Johne hastalığının kontrolünü zorlaştırmaktadır [23, 36]. IgG1 sınıfı antikorların subklinik enfeksiyonun özellikle orta ve ileri aşamalarında tespit edilebileceği bildirilmiştir [23].

Paratüberkülozun bilinen en önemli özelliği ince bağırsağın orta ve alt segmentlerinde granülom oluşturmasıdır. Subklinik evredeki hayvanlarda küçük granülomlar gözlenmektedir [34]. Bu granülamatöz lezyonların, Map'in bağırsağın diğer bölümleri ile lenf düğümlerine yerleşmesini engellemek ve kontrol etmek için konakçı tarafindan oluşturulan geç immun yanıtla ilişkili olabileceği düşünülmüştür [14]. Ancak bu granülomların mikobakteriler tarafindan enfeksiyon yerine yeni makrofajları toplamak ve yer değiştirmek için kullanabileceği de ileri sürülmüştür [14]. Kısacası Map'in bağırsağın başka bölümleri ile meme bezleri ve mezenterik lenf düğümleri gibi diğer organları enfekte etmek için granülomlardan köprü olarak yararlanabileceği belirtilmiştir [20]. Granülomların içinde Map bulunduran makrofajlar ve dev hücreler bulunmaktadır. $\mathrm{CD}^{+} \mathrm{T}$ hücreleri ve $\mathrm{CD}^{+} \mathrm{T}$ hücreleri bu granülomların etrafını çevreler. $\mathrm{Bu}$ aşamada en önemli sitokin, $\gamma \delta \mathrm{T}$ hücreleri ve $\mathrm{CD}^{+} \mathrm{T}$ hücreleri tarafindan salınan TNF- $\alpha$ 'dır. TNF- $\alpha$, makrofajları toplayarak enfeksiyonun kontrol altına alınmasına yardımcı olur. Ancak doku hasarına da neden olabilir. Makrofajlar tarafından salınan IL-10, CD4 ${ }^{+} \mathrm{T}$ hücrelerini baskılayarak IFN- $\gamma$ üretimini azaltır. IFN- $\gamma$ düzeyinin azalması nedeniyle yeni toplanan makrofajlar kalıcı enfekte olma eğilimindedir. Bu aşamada sitotoksik $\mathrm{T}$ hücre popülasyonu $\left(\mathrm{CD} 8^{+}\right.$ve $\gamma \delta \mathrm{T}$ hücreleri) fark11 roller oynamaktadır. $\gamma \delta \mathrm{T}$ hücreleri $\mathrm{CD} 4^{+} \mathrm{T}$ hücre proliferasyonunu baskılarken, $\mathrm{CD} 8^{+} \mathrm{T}$ hücre proliferasyonunu korur. Ayrıca $\gamma \delta \mathrm{T}$ hücreleri granülasyon oluşumuna neden olur ve yangısal yanıtı kisıtlar. Humoral immun yanıt sinırlıdır. $\gamma \delta \mathrm{T}$ hücrelerinden ve $\mathrm{CD} 4^{+} \mathrm{T}$ hücrelerinden salınan IFN $\gamma$, makrofajların hücre içi Map'i öldürmesi için yeterli değildir. IFN- $\gamma$ yanıt1 yeterli olmadığ 1 için IgG1, IgG2'ye dönüşemez ve IgG1 tip immunglobulin yanıtı devam eder [32].
Erken subklinik aşamada olan hayvanların ileal dokularında IFN- $\gamma$, TNF- $\alpha$, IL-1 $\alpha$ ve IL-6 gibi pro-enflamatuar sitokinlerin aşırı sentezine bağl1 olarak $\mathrm{CD}^{+} \mathrm{T}$ hücrelerinin oldukça fazla çoğald1$\breve{g} 1$ Th1 tip hücresel immun yanıtının baskın olduğu gözlenmiştir [12, 19]. Fakat hastalıkta Th1 hücresel yanıtın, artan antikor yanıtı ile birlikte azaldığı bildirilmiş, ancak bu değişikliğin arkasındaki nedenin ve ne zaman olduğunun kesin olarak bilinmediği belirtilmiştir [23]. Subklinik aşamada düzenleyici $\mathrm{T}$ (regulatory $\mathrm{T}$, Treg) hücrelerinin düşük düzeyde Map antijenleri ile uyarıldığı ve Map'e karşı gelişecek etkili bir T hücre yanıtını kısıtladığı açıklanmıştır [15]. Ayrıca bu dönemin hastalığın subklinik formdan klinik forma dönüştüğünün de göstergesi olduğu ifade edilmiştir [28]. Treg hücrelerinin immunomodülatör etkilerini IL-10 ve TGF- $\beta$ üreterek gösterdikleri bilinmektedir [15]. Roussey ve ark. [28], sığır Treg hücrelerinin Map'e karşı spesifik olmadığını ve non-spesifik etkili bu Treg hücrelerinin in vitro koşulda Th1 sitokinlerinden IFN- $\gamma$ ile sitotoksik $\mathrm{T}$ hücrelerinin sitotoksik fonksiyonunda görevli ve perforini kodlayan önemli bir protein olan profilin-1'in üretimini baskıladığını ortaya koymuşlardır.

\section{Klinik Evre}

Map ile enfekte hayvanlarda subklinik fazın geç dönemi ile erken klinik faz döneminde sürekli ishal, yem yemede azalma, halsizlik, kas erimesi ve süt üretiminde azalma gibi klinik belirtiler gözlenmekte ve hastalık en son aşamada ölüme neden olmaktadır [23]. Klinik bulguların ilerlediği dönemde, aşır1 ishal, zayıflama ve kaşeksi görülmektedir [20]. Hayvanlar aşırı zayıftır ve bağırsakta fonksiyon kaybı nedeniyle özellikle albümin başta olmak üzere serum proteinlerinin konsantrasyonunun düşmesi sonucu submandibular ödem ortaya çıkmaktadır $[10,20]$. Subklinik evrede olduğu gibi bu evrede de süt verimi azalır [23]. Ayrıca klinik aşamada Map, sürekli olarak dışk1, süt ve kolostrum ile etrafa saçılmaktadır. Bu durum ise Map'in sürü içinde yayı$11 \mathrm{~m}$ riskini arttırmaktadır [23].

Klinik belirti gösteren hayvanlarda intestinal mukozada Map yükü yüksek konsantrasyona ulaştığ için dışkı kültürü ile polimeraz zincir reaksiyonu pozitif sonuç verir ve bu hayvanlarda antikorlar 
ELIZA testi ile de tespit edilebilir [18]. Ayrica bu dönemde süt ve kolostrumda da etkenin tespit edilebildiği [25] ve gebe hayvanların bakteriyi uterusta yavruya geçirebildiği [39] rapor edilmiştir. Lenfosit, epiteloid makrofaj ve dev hücre infiltrasyonu ile kalınlaşan intestinal mukozada villus ve mikrovillusların fonksiyonlarını kaybettiği saptanmıştır [20]. İntestinal mukozadaki kalınlaşma ile intestinal duvarda granülomatöz yangı gibi patolojik lezyonların varlığı protein kaybına neden olan enteropatinin kanıtı olarak belirtilmiştir [23, 36]. Ayrıca Map'in, supramammar, karaciğer ve akciğer lenf dügümleri de dâhil olmak üzere bağırsak dışında diğer organlara da yayılabildiği bildirilmiştir [20].

Klinik bulguların görülmesiyle birlikte immun yanıtın Th1'den Th2 aracılığıyla gelişen immun yanita dönüştüğü gözlenmiştir [7]. Antikor üreten $B$ hücrelerinin $\operatorname{arttığ} 1$ ve bununla orantılı bir şekilde serum antikor düzeylerinin de tespit edilebilebilir şekilde yükseldiği ortaya konulmuştur [23]. İmmun yanıtta bu değişiklikler belirlenmiş olmasına rağmen, bu değişime neden olan faktörler henüz aydınlatılamamıştır [23]. İmmun yanıtın değişimi ile periferal mononüklear kan hücrelerinde, ileum ve ilgili lenf nodüllerinde IL-10, TGF- $\beta$, IL-4 gibi anti-enflamatuar sitokinlerin baskın olduğu gözlenmiştir [12, 23]. Ayrıca Treg hücreleri (CD4+CD25+) tarafindan IL-10 ve TGF- $\beta$ sentezinin sağlandığ 1 ve böylece $\mathrm{CD}^{+} \mathrm{T}$ hücre popülasyonun daha çok baskılandığ 1 , Th2 hücre yanıtının baskılanması nedeniyle B hücre yanıtının azaldığı bildirilmiş, ancak B hücre yanıtının diğer deyişle IgG1 yanıtının bu aşamada hala ölçülebilir düzeyde kaldığ 1 açıklanmıştır [36].

Sonuç olarak, bugüne kadar paratüberküloz için etkenin mevcut immun sistemden kaçma stratejileri nedeniyle uygun bir koruma ve kontrol stratejisi belirlenememiş, etkili bir aşı geliştirilememiştir. Spesifik bir aşı veya tedavinin bulunabilmesi için Map'in, immun sistemden kaçış mekanizmalarının ve patogenezisinin anlaşılması gerekmektedir. $\mathrm{Bu}$ derlemede, Map'in enfeksiyon oluşturma mekanizmaları ile immun sistemi nasıl yanılttığı ve kalıc1 enfeksiyonun nasıl oluştuğu açıklandı. Yapılan literatür taramalarında detaylı çalışmalarla karşılaşılmasına rağmen, hastalığın patogenezinde hala açıklanamayan mekanizmaların bulunduğu ve hastalığın oluşum mekanizmasının henüz tam olarak anlaşılamadığ 1 görülmektedir. Bu nedenle, Map'in virülens faktörleri ile hastalığın patogenezi ve konakçının genetik duyarlılığı gibi konuların daha iyi anlaşılabilmesi için daha ayrıntılı çalışmalara gereksinim olduğu söylenebilir. Ancak bu detaylı çalışmalar sonucunda, etkili bir tedavi veya aşı bulunarak ya da yeni tanı testleri geliştirilerek hastalığın kontrolü yapılabilir ve böylece hayvan sağlı̆̆ının yanısıra insanlar için de gıda güvenliği sağlanabilir.

\section{Kaynaklar}

1. Arsenault RJ, Li Y, Bell K, Doig K, Potter A, Griebel PJ, Kusalik A, Napper S, (2012). Mycobacterium avium subsp. paratuberculosis inhibits interferon gamma induced signaling in bovine monocytes: insights into the cellular mechanisms of Johne's disease. Infect Immun. 80, 3039-3048.

2. Arsenault RJ, Li Y, Maattanen P, Scruten E, Doig K, Potter A, Griebel P, Kusalik A, Napper S, (2013). Altered Toll-like receptor 9 signaling in Mycobacterium avium subsp. paratuberculosis-infected bovine monocytes reveals potential therapeutic targets. Infect Immun. 1, 226-237.

3. Arsenault RJ, Maattanen P, Daigle J, Potter A, Griebel P, Napper S, (2014). From mouth to macrophage: mechanisms of innate immune subversion by Mycobacterium avium subsp. paratuberculosis. Vet Res. 45, 54.

4. Ayele WY, Machackova M, Pavlik I, (2001). The transmission and impact of paratuberculosis infection in domestic and wild ruminants. Vet Med-Czech. 46, 205-224.

5. Baquero MM, Plattner BL, (2016). Bovine WC1(+) $\gamma \delta$ T lymphocytes modify monocyte-derived macrophage responses during early Mycobacterium avium subspecies paratuberculosis infection. Vet Immunol Immunopathol. 170, 65-72.

6. Basler T, Geffers R, Weiss S, Valentin-Weigand P, Goethe R, (2008). Mycobacterium avium subspecies induce differential expression of proinflammatory mediators in a murine macrophage model: evidence for enhanced pathogenicity of Mycobacterium avium subspecies paratuberculosis. Immunobiology. 213, 879-888.

7. Bassey EO, Collins MT, (1997). Study of T-lymphocyte subsets of healthy and Mycobacterium avium subsp. paratuberculosis-infected cattle. Infect Immun. 65, 4869-4872.

8. Begg DJ, de Silva K, Carter N, Plain KM, Purdie A, Whittington RJ, (2011). Does a Th1 over Th2 dominancy really exist in the early stages of Mycobacterium avium subspecies paratuberculosis infections? Immunobiology. 216, 840-846.

9. Behr MA, Kapur V (2008): The evidence for Mycobacterium paratuberculosis in Crohn's disease. Curr Opin Gastroenterol. 24, 17-21.

10. Clarke CJ (1997): The pathology and pathogenesis of paratuberculosis in ruminants and other species. J Comp Pathol. 116, 217-261.

11. Collins MT, Wells SJ, Petrini KR, Collins JE, Schultz RD, Whitlock RH, (2005). Evaluation of five antibody detection tests for diagnosis of bovine paratuberculosis. Clin Diagn Lab Immunol. 12, 685-692. 
12. Coussens PM, Verman N, Coussens MA, Elftman MD, McNulty AM, (2004). Cytokine gene expression in peripheral blood mononuclear cells and tissues of cattle infected with Mycobacterium avium subsp. paratuberculosis: evidence for an inherent proinflammatory gene expression pattern. Infect Immun. 72, 1409-1422.

13. Çetinkaya B, Muz A, Ertaş B, Öngör H, Sezen Y, Gülcü B, (2000). Süt ineklerinde paratüberküloz prevalansının polimeraz zincir reaksiyonu (PZR) ile saptanması. Turk J Vet Anim Sci. 24, 371-379.

14. Davis JM, Ramakrishnan L, (2009). The role of the granuloma in expansion and dissemination of early tuberculous infection. Cell. 136, 37-49.

15. de Almeida DE, Colvin CJ, Coussens PM, (2008). Antigenspecific regulatory $T$ cells in bovine paratuberculosis. Vet Immunol Immunopathol. 125, 234-245.

16. Ellingson JLE, Anderson JL, Koziczkowski JJ, Radcliff RP, Sloan, SJ, Allen SE, Sullivan NM, (2005). Detection of viable Mycobacterium avium subsp. paratuberculosis in retail pasteurized whole milk by two culture methods and PCR. J Food Prot. 68, 966-972.

17. Gillan S, O'Brien R, Hughes AD, Griffin JF, (2010). Identification of immune parameters to differentiate disease states among sheep infected with Mycobacterium avium subsp. paratuberculosis. Clin Vaccine Immunol. 17, 108-117.

18. Kalis CH, Barkema HW, Hesselink JW, van Maanen C, Collins MT, (2002). Evaluation of two absorbed enzymelinked immunosorbent assays and a complement fixation test as replacements for fecal culture in the detection of cows shedding Mycobacterium avium subspecies paratuberculosis. J Vet Diagn Invest. 14, 219-224.

19. Khalifeh MS, Stabel JR, (2004). Effects of gamma interferon, interleukin-10, and transforming growth factor beta on the survival of Mycobacterium avium subsp. paratuberculosis in monocyte-derived macrophages from naturally infected cattle. Infect Immun. 72, 1974-82.

20. Lamont EA, (2012). Survival strategies of Mycobacterium avium subsp. paratuberculosis in a variety of microenvironments. PhD Thesis, The University of Minnesota, Minnesota, United States.

21. Lockhart E, Green AM, Flynn JL, (2006). IL-17 production is dominated by $T$ cells rather than CD4 $T$ cells during Mycobacterium tuberculosis infection. J Immunol. 177, 4662-4669.

22. Magombedze G, Eda S, Stabel J, (2015). Predicting the role of IL-10 in the regulation of the adaptive immune responses in Mycobacterium avium subsp. paratuberculosis infections using mathematical models. PLoS One. 10, e0141539.

23. Mallikarjunappa S, (2013). Cytokine gene expression in Holstein-Friesian and Jersey Calves infected with Mycobacterium avium subsp. paratuberculosis. Master Thesis. The University of Guelph, Ontario, Canada.

24. Nielsen SS, (2008a). Transtions in diagnostic tests used for detection of Mycobacterium avium subsp. paratuberculosis infections in cattle. Vet Microbiol. 132, 274-282.

25. Nielsen SS, Bjerre H, Toft N, (2008b). Colostrum and milk as risk factors for infection with Mycobacterium avium subspecies paratuberculosis in dairy cattle. J Dairy Sci. 91, 46104615.
26. Plattner BL, Doyle RT, Hostetter JM, (2009). Gamma-delta T cell subsets are differentially associated with granuloma development and organization in a bovine model of mycobacterial disease. Int J Exp Pathol. 90, 587-597.

27. Robinson M, O’Brien R, Mackintosh C, Griffin F, (2008). Differential immune responses of red deer (Cervus elaphus) following experimental challenge with Mycobacterium avium subsp. paratuberculosis. Clin Vaccine Immunol. 15, 963969.

28. Roussey JA, Steibel JP, Coussens PM, (2014). Regulatory T cell activity and signs of $T$ cell unresponsiveness in bovine paratuberculosis. Front Vet Sci. 1, 20.

29. Sanjuan MA, Milasta S, Green DR, (2009). Toll-like receptor signaling in the lysosomal pathways. Immunol Rev. 227 , 203-220.

30. Secott TE, Lin TL, Wu CC, (2002). Fibronectin attachment protein is necessary for efficient attachment and invasion of epithelial cells by Mycobacterium avium subsp. paratuberculosis. Infect Immun. 70, 2670-2675.

31. Selvaraj P, Afsal K, Harishankar M, (2015). Vitamin D and macrophage functions in tuberculosis. Macrophage. 2, e756.

32. Sohal JS, Singh SV, Tyagi P, Subhodh S, Singh PK, Singh AV, Narayanasamyc K, Sheoran N, Komal Singh Sandhu, (2008). Immunology of mycobacterial infections: with special reference to Mycobacterium avium subspecies paratuberculosis. Immunobiology. 213, 585-598.

33. Sommer S, Pudrith CB, Colvin CJ, Coussens PM, (2009). Mycobacterium avium subspecies paratuberculosis suppresses expression of IL-12p40 and iNOS genes induced by signalling through CD40 in bovine monocyte-derived macrophages. Vet Immunol Immunopathol. 128, 44-52.

34. Tiwari A, VanLeeuwen JA, McKenna SL, Keefe GP, Barkema HW, (2006). Johne's disease in Canada Part I: clinical symptoms, pathophysiology, diagnosis, and prevalence in dairy herds. Can Vet J. 47, 874-882.

35. Tizard IR, (2009). Veterinary Immunology, 8th edition, Saunders Elsevier, St. Louis, Missouri, p: 11-16.

36. Wadhwa A, Kumar N, Velasco-Villa A, Eda S, (2013). Overview of Johne's disease immunology. Veterinary World. 6, 901-904

37. Waters WR, Miller JM, Palmer MV, Stabel JR, Jones DE, Koistinen KA, Steadham EM, Hamilton J, Davis WC, Bannantine JP, (2003). Early induction of humoral and cellular immune responses during experimental Mycobacterium avium subsp. paratuberculosis infection of calves. Infect Immun. 71, 5130-5138.

38. Weiss DJ, Souza CD, (2008). Modulation of mononuclear phagocyte function by Mycobacterium avium subsp. paratuberculosis. Vet Pathol. 45, 829-841.

39. Whittington RJ, Windsor PA, (2009). In utero infection of cattle with Mycobacterium avium subsp. paratuberculosis: A critical review and meta-analysis. Vet J. 179, 60-69.

40. Woo SR, Czuprynski CJ, (2008). Tactics of Mycobacterium avium subsp. paratuberculosis for intracellular survival in mononuclear phagocytes. J Vet Sci. 9, 1-8.

41. Yardımcı H, (2006). Mycobacterium infeksiyonlarl. Editörler: Aydın N, Paracıkoğlu J. Veteriner Mikrobiyoloji, İlke-Emek Yayınları, Ankara, s: 87-107. 